\title{
Global city: the occupational layer
}

\author{
Isabel Loureiro $^{1 *}$, Nelson Costa $^{1}$, Pedro Arezes ${ }^{1}$
}

\begin{abstract}
Nowadays discussion on global cities concept is being addressed on European level. The concept is a consequence of multiplicities of globalization processes adding different layers according to social, economic and environmental requirements. Cities must also be seen as working systems, with the same needs and requirements in terms of safety and well-being that are considered for other systems. In this paper Authors address the evidences that support the importance of this additional layer. Different sources were used in order to obtain the data related to working systems and their relation to the global cities concept. The conducted systematic review indicate that the search words: sustainability, occupational and global city were not crossed for research. Furthermore, challenges that cities are facing must be understood as additional source of motivation and innovation towards a global city. Cities must also be seen as working systems, with the same needs and requirements in terms of safety and well-being that are considered for other systems.
\end{abstract}

Keywords: Global city, layers, occupational, holistic approach.

\section{Introduction}

According to Rode and Burdett (2012), cities are a social, ecological, and economic system within a defined geographic territory. These three pillars are also the base of the sustainability concept as stated by to Zink (2014). Sustainability must be understood as the simultaneous pursuit of economic, ecological and social objectives represented by a triangle-model including the time dimension (Figure 1).

3-Pillar Model

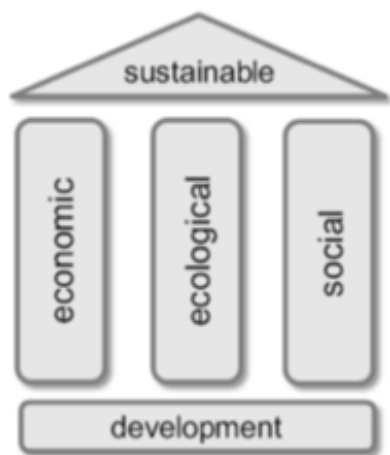

Triangle Model

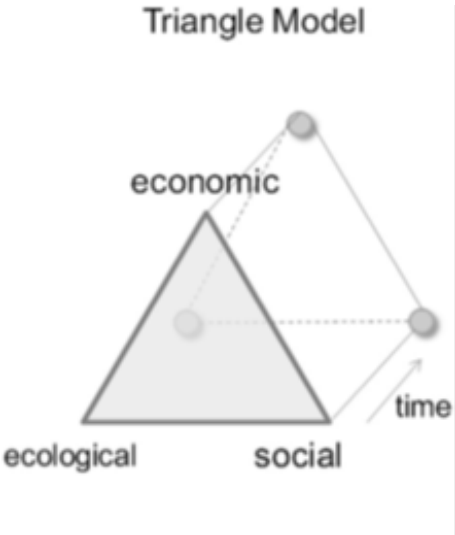

Figure 1: Sustainability pillars (from Zink, 2014). 
This dimension is very important as at business level, corporate sustainability requires a long-term business orientation as a basis for satisfying stakeholders' needs now and in the future. Dyllick and Hockerts (2002) goes further stating that at the business level sustainability is often equated with eco-efficiency, socio-efficiency, eco-effectiveness, socio-effectiveness, sufficiency and ecological equity. Meaning that besides financial capital, companies must also considered natural, human, and social capital.

Insch and Florek, (2008) identified the most important value of a city as city's resident population. Both residents' quality of life and their satisfaction with their city of residence are the most important city goals to achieve. For that, cities should have certain features to improve people's life quality and satisfaction so they can be identified with the place and remain (Węziak-Białowolska, 2016). In order to make a city livable, four levels of features were identified by the authors, namely: 1. Physical features (including Culture, Green areas Public transport efficiency and availability, Sports grounds and facilities among others), 2. Features of a social nature (Neighborhood networks) 3. Environmental features (strategic plans for landscape preservation, acoustic, quality of air, waste management among others) 4. Economical and 5. Institutional features. Labour market opportunities are included on the economical level. Institutional factors reflecting quality and efficiency of local government are assessed by level 5 .

A question arises: Does a city with sustainable plans on these four areas can be considered a global city?

Overtime, the concept of Global cities has been related to central nodes in a worldwide hierarchy of urban centers (Timberlake et al., 2014). As stated by Csomós and Tóth (2016), Global cities are the major command and control centres of the world economy and, on the other hand, as the most significant sites of the production of innovation. Sassen (2005) goes further stating that global cities are sites of production, including the production of innovation, in leading industries. Nowadays discussion on global cities concept is being addressed on European level. Several layers were already identified as a part of this concept. For Floater and Rode (2011) there are three groups of cities that will be particularly important for the global economy and climate: Emerging Cities, Global Megacities and Mature Cities. Sassen (2005) state that Global cities around the world are the terrain where multiplicities of globalization processes happen, being this processes what globalization is about. New types of operations exists on today's cities: political, economic, "cultutal," subjective bringing different layers to the concept of global cites such as, cultural, user-friendly and amenity, assessable, sharing, energy, smart, green or city factory age-friendly cities and communities (Sasaki, 2010; Lazaroiu and Roscia, 2012; Buffel and Phillipson, 2016; Nieuwenhuijsen and Khreis, 2016).

The fact is that cities are made for citizens leave, work, and study among other things. Citizens are integrated in a social, community and working context. So cities as a global concept must include all the possible layers creating an identity recognized by those who live and work there. Therefore, working systems may also affect citizens' quality of life. According to Rasmussen (2000) "Any workplace is an integrated part of a complex, dynamic socio-technical system". This is a complex type of system were different levels can be identified, from productive process to normative governmental rules. Each level is related to a research area (engineering, psychology, economics, political science), being study separately by different academic disciplines. Several external conditions can have 
influence on each level operation affecting the system control. Rasmussen (2000) calls them "environment stressors". They can be changing political climate and public awareness, changing market conditions and financial pressure, changing competence and levels of education, technological changes. Each of these stressors can have an effect on a particular system level. Usually, the different levels of the socio-technical system are studied separately by decomposition of the system into their functional systems. Considering this point of view, managements strategies often are dissociated from the productive process, in terms of human factors, take for example the situations where companies give too much importance to political changing's and as a consequence, they implement several structural changes in the organizations like less payment or mass redundancies (Loureiro et al., 2010).

This paper briefly explores a new line of discussion about the inclusion of an occupational layer on the global cities concept. Authors strong believe that this layer is missing, as citizens that are leaving on cities can also work on those cities. Cities must also be seen as working systems, with the same needs and requirements in terms of safety and well-being that are considered for other systems. In this paper Authors address the evidences that support the importance of this additional layer. Different sources were used in order to obtain the data related to working systems and their relation to the global cities concept.

\section{Methodology}

The adopted inclusion criteria included only original studies written in English and published until December 2015. This period did not consider an initial date in order to understand the tendency under the importance of the occupational layer on a global city system. This criterion was maintained during the entire process.

Papers were the only type of publication selected from the initial options which also included Journal, book and References works (Castellucci et al., 2016).

The search terms used were "Global City", "Occupational", "Sustainability" and the initial results were 1,141 papers divided by 20 different topics and 20 different publication titles. The next step was to address only the topics related with "Health", "United States", "Social", "Europe", "Urban", "World" and "Community" for those were considered the most probable to have publications of relevance to the present study.

Regarding the publication titles, the research itself was focused on generic themes that included the keywords. Because authors didn't want to focus the review on specific environmental subjects such as energy, waste, and technology; ecology, forest, green areas and climate change. For that reason, the titles selected were "World development", "Procedia - Social and Behavioural Sciences", "Science of the Total Environment" and "Cities". The final result was 15 eligible papers. After careful screening of these 15 papers, 1 was removed due to access restrictions and 2 others were also removed due for being "contents" on the issue. Figure 2 shows the flowchart of the PRISMA methodology and the numbers of results.

Information was gathered on a table according to different topics: reference, type of research and aim and, relevant results. 


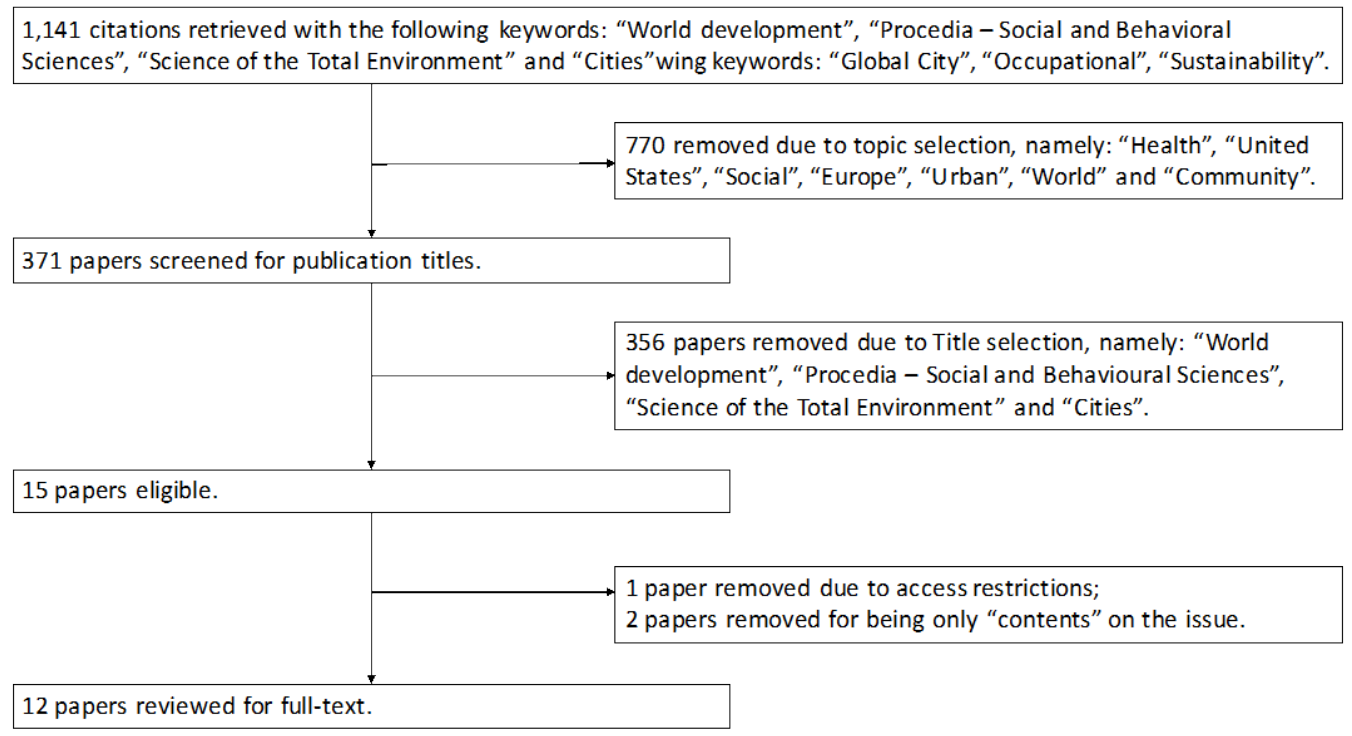

Figure 2 - PRISMA flowchart details.

\section{Results}

Results from the systematic review are presented in Table 1 . The 12 selected papers are from 1993 to 2013. These papers were presented as historical research, applied research, fundamental research, case study (qualitative research) and exploratory research. It is a fact that using Keywords can help to improve search results.

Table 1 - Sumary of the 12 papers reviewd for fulltext.

\begin{tabular}{|l|l|l|}
\hline Authors & Research and aim & Relevant results \\
\hline $\begin{array}{l}\text { Thomas and } \\
\text { Price (1999) }\end{array}$ & $\begin{array}{l}\text { Historical research with } \\
\text { retrospective information on the } \\
\text { role of the historical demographic } \\
\text { transition in Europe to establish } \\
\text { whether the abandonment of the } \\
\text { Bucharest ideology is justified on } \\
\text { the basis of subsequent theoretical } \\
\text { developments in fertility studies, } \\
\text { and by global demographic trends } \\
\text { over the period. }\end{array}$ & $\begin{array}{l}\text { Future trends in population growth will be } \\
\text { frome ongoing liberalisation of trade and } \\
\text { investment under the aegis of globalisation. }\end{array}$ \\
\hline Hatz (2008) & $\begin{array}{l}\text { Historical research presenting an } \\
\text { historical overview of Vienna and } \\
\text { urban planning perspectives. }\end{array}$ & $\begin{array}{l}\text { The tensions between preserving the social } \\
\text { and cultural heritage of the city and } \\
\text { alike for the global transformation of } \\
\text { economy and urban areas will be the major } \\
\text { challenge for urban planning in Vienna in } \\
\text { the upcoming future. }\end{array}$ \\
\hline
\end{tabular}




\begin{tabular}{|c|c|c|}
\hline $\begin{array}{l}\text { Özcürea, } \\
\text { Demirkayab, } \\
\text { Eryi } \div \text { itc } \\
(2011)\end{array}$ & $\begin{array}{l}\text { Applied research on OMV Samsun } \\
\text { Elektrik to analyze criteria for } \\
\text { sustainability definition and } \\
\text { relevance of workers participation } \\
\text { as a part of the solution to triple } \\
\text { crisis in the European Union And } \\
\text { Turkey. }\end{array}$ & $\begin{array}{l}\text { OMV creates employment as a sustainable } \\
\text { company and employee participation } \\
\text { found both as a part of the solution to triple } \\
\text { crisis in the EU and Turkey. OMV declared } \\
\text { that health, safety, security and } \\
\text { environment (HSSE), community relations } \\
\text { and social responsibility are seen as integral } \\
\text { to business activities. Responsible } \\
\text { behaviour and sustainability } \\
\text { management are firmly embedded in } \\
\text { vision and strategy, and are crucial to } \\
\text { surmounting future challenges that the } \\
\text { company will face as an integrated energy } \\
\text { Group. These include shortages of skilled } \\
\text { personnel, as well as work and process } \\
\text { safety, and the need to provide energy } \\
\text { markets with secure energy supplies whilst } \\
\text { simultaneously reducing greenhouse gas } \\
\text { emissions. }\end{array}$ \\
\hline $\begin{array}{l}\text { Madaleno and } \\
\text { Gurovich } \\
(2004)\end{array}$ & $\begin{array}{l}\text { Case study performed in Santiago } \\
\text { city to discuss the validity of the } \\
\text { "urban versus rural" dichotomy in } \\
\text { scientific literature, statistics and } \\
\text { urban planning practice, especially } \\
\text { in empirical studies developed } \\
\text { around the issue of vegetable and } \\
\text { animal farming inside and around } \\
\text { cities. }\end{array}$ & $\begin{array}{l}\text { The environmentally balanced growth of } \\
\text { cities must be reached exploring interactions } \\
\text { between market driven growth and } \\
\text { spatially driven planning. Peri-urban areas } \\
\text { are conflicting ring spaces and wealth is } \\
\text { synonymous with healthy development, } \\
\text { particularly in large urban agglomerations }\end{array}$ \\
\hline $\begin{array}{l}\text { Hermann } \\
\text { Schwengel } \\
(2008)\end{array}$ & $\begin{array}{l}\text { Fundamental research on } \\
\text { Emerging powers concepts and } \\
\text { types. }\end{array}$ & $\begin{array}{l}\text { With the process of emerging powers, the } \\
\text { global division of labor, the } \\
\text { empowerment of mobile capital against } \\
\text { immobile labor, of qualified professional } \\
\text { work against nothing but labor, of formal } \\
\text { members against informal members, of } \\
\text { insiders against outsiders, the concept of } \\
\text { society as a living, acting, and reflecting } \\
\text { body has to be reconfigured. Societies have } \\
\text { to locate themselves within the global } \\
\text { division of labor, they have to relate their } \\
\text { own social structure to long-term change in } \\
\text { the global social structure-societies in the } \\
\text { global societies-and they have to } \\
\text { communicate this change within their own } \\
\text { conflict structures and between } \\
\text { transnational classes, groups, and } \\
\text { professions }\end{array}$ \\
\hline
\end{tabular}


Table 2 - Sumary of the 12 papers reviewd for fulltext (continuation).

\begin{tabular}{|c|c|c|}
\hline Authors & Research and aim & Relevant results \\
\hline $\begin{array}{l}\text { Ingham } \\
\text { (1993) }\end{array}$ & $\begin{array}{l}\text { Exploratory study on the } \\
\text { interactions between the early } \\
\text { concerns of development } \\
\text { economics highlighting the } \\
\text { development in the context of } \\
\text { economic history. industrialization } \\
\text { and modernization, "people- } \\
\text { centered" development, } \\
\text { sustainability, political and civil } \\
\text { liberties and development ethics. }\end{array}$ & $\begin{array}{l}\text { Development must be analyzed in the } \\
\text { context of economic history, of } \\
\text { industrialization and modernization, } \\
\text { "people-centered" development, } \\
\text { sustainability, political and civil liberties and } \\
\text { development ethics. }\end{array}$ \\
\hline$\frac{\text { Yankholmes, }}{2013}$ & $\begin{array}{l}\text { Research study based on Multi- } \\
\text { strategy or mixed method to } \\
\text { examin residents perceptions } \\
\text { towards tourism development in } \\
\text { six communities in Danish-Osu }\end{array}$ & $\begin{array}{l}\text { In general, the findings show a fair } \\
\text { knowledge of issues that affect residents' } \\
\text { livelihoods. Specific community needs } \\
\text { mentioned by respondents suggest that } \\
\text { attention should be paid to improving access } \\
\text { to social amenities and spaces. }\end{array}$ \\
\hline $\begin{array}{l}\text { Hancock, } \\
1999\end{array}$ & $\begin{array}{l}\text { Fundamental research on Health } \\
\text { care reform and reform for health. }\end{array}$ & $\begin{array}{l}\text { This author presents the Human } \\
\text { development model integrating the } \\
\text { environmental, social and economic sectors } \\
\text { if human development is to be enhanced. }\end{array}$ \\
\hline Cohen, 2006 & $\begin{array}{l}\text { Research study on the Ecological } \\
\text { modernization and its discontents: } \\
\text { The American environmental } \\
\text { movement's resistance to an } \\
\text { innovation-driven future }\end{array}$ & $\begin{array}{l}\text { Ecological modernization, because it } \\
\text { provides a set of strategies for harmonizing } \\
\text { environmental protection with economic } \\
\text { growth, provides a pre^t-a - porter strategy } \\
\text { for achieving political goal. } \\
\text { The historical development of organized } \\
\text { environmentalism in the United States and } \\
\text { its general tendency to privilege the interests } \\
\text { of landscape and wildlife protection over } \\
\text { concerns about public health and industrial } \\
\text { pollution. }\end{array}$ \\
\hline $\begin{array}{l}\text { Davoudi, } \\
\text { Wishardt, } \\
\text { Strange (2010) }\end{array}$ & $\begin{array}{l}\text { Exploratory study on } \\
\text { consequences of Europe ageing. }\end{array}$ & $\begin{array}{l}\text { Concerns raised on the analyzed scenarios } \\
\text { are partly a result of the tendency of both } \\
\text { young people and migrants to move to large } \\
\text { metropolitan areas for work and } \\
\text { consequently settle in already crowded } \\
\text { centres. What does appear clear from both } \\
\text { scenarios is that without enticements, either } \\
\text { fiscal or other, to move to areas suffering } \\
\text { depopulation, a laissez faire approach to } \\
\text { population movement, whether indigenous } \\
\text { or not, will not address the problems faced } \\
\text { by struggling peripheral areas. }\end{array}$ \\
\hline
\end{tabular}




\begin{tabular}{|l|l|l|}
\hline $\begin{array}{l}\text { Elson } \\
(1995)\end{array}$ & $\begin{array}{l}\text { Historical research discussing } \\
\text { strategies for introducing gender } \\
\text { analysis into the macroeconomic } \\
\text { models and evaluates the strengths } \\
\text { and weaknesses of the models } \\
\text { from a gender perspective. }\end{array}$ & $\begin{array}{l}\text { Gender-awareness in macroeconomic } \\
\text { analysis requires that we look at economic } \\
\text { models from the standpoint of women's } \\
\text { lives, in which much time is devoted to } \\
\text { unpaid work in social reproduction as well } \\
\text { as paid work in production; and that we } \\
\text { recognize unequal gender relations as an } \\
\text { intervening variable that structures } \\
\text { economic processes at macro, meso and } \\
\text { micro levels. }\end{array}$ \\
\hline $\begin{array}{l}\text { Munasinghe } \\
(1993)\end{array}$ & $\begin{array}{l}\text { Case study developed in several } \\
\text { country with a cover a range of } \\
\text { practical valuation methods }\end{array}$ & $\begin{array}{l}\text { This paper explains the key role of } \\
\text { environmental economics in incorporating } \\
\text { environmental concerns into decision } \\
\text { making and in facilitating the more efficient } \\
\text { management of natural resources as a step } \\
\text { toward sustainable development. }\end{array}$ \\
\hline
\end{tabular}

The 12 selected papers are from 1993 to 2013. These papers were presented as historical research, applied research, fundamental research, case study (qualitative research) and exploratory research. It is a fact that using Keywords can help to improve search results. The paper from Hatz (2008) was the only one that presented keywords. The Keywords are: European city, post-modern city, social cohesion, historic city centre, urban regeneration and urban governance. The focus of research was in economics ( 3 papers), Health (4 papers), urban planning (2 papers), Ecology (1 paper) and corporate sustainability (1 paper).

Discussion on cities concept considered the city as a place to live. None of the papers referred cities as the place to work or to develop working systems. Economics was mentioned several times as being a pillar of sustainability concept. But economics is seen as the profits that cities can generate because of the companies implementation and development associated. Madaleno and Gurovich (2004) pointed out the need of a balance between market driven growth and cities spatially driven planning.

Two of the search words were used by Özcürea et al. (2011). This was the only paper that related occupational issues with sustainability focusing the research on sustainability definition and relevance of workers participation. Global cities concept was presented by Schwengel (2008). This author refers to this concept as a possible emerging power. An important asset is presented by Hancock (1999). Even though this paper is from 1999, this author shows the importance "to assert that the central purpose of our society should be to improve the health, wellbeing and quality of life of the population. And we need to bring together the broad range of sectors in society whose activities affect health in a comprehensive and collaborative approach to promoting health and enhancing human development". Considering the "Human and Ecosystem Health" cited by this author: "Human development and the achievement of human potential requires a form of economic activity that is environmentally and socially sustainable in this and future generations". Figure 2 represents the focus of Human model development based on previous definition. 


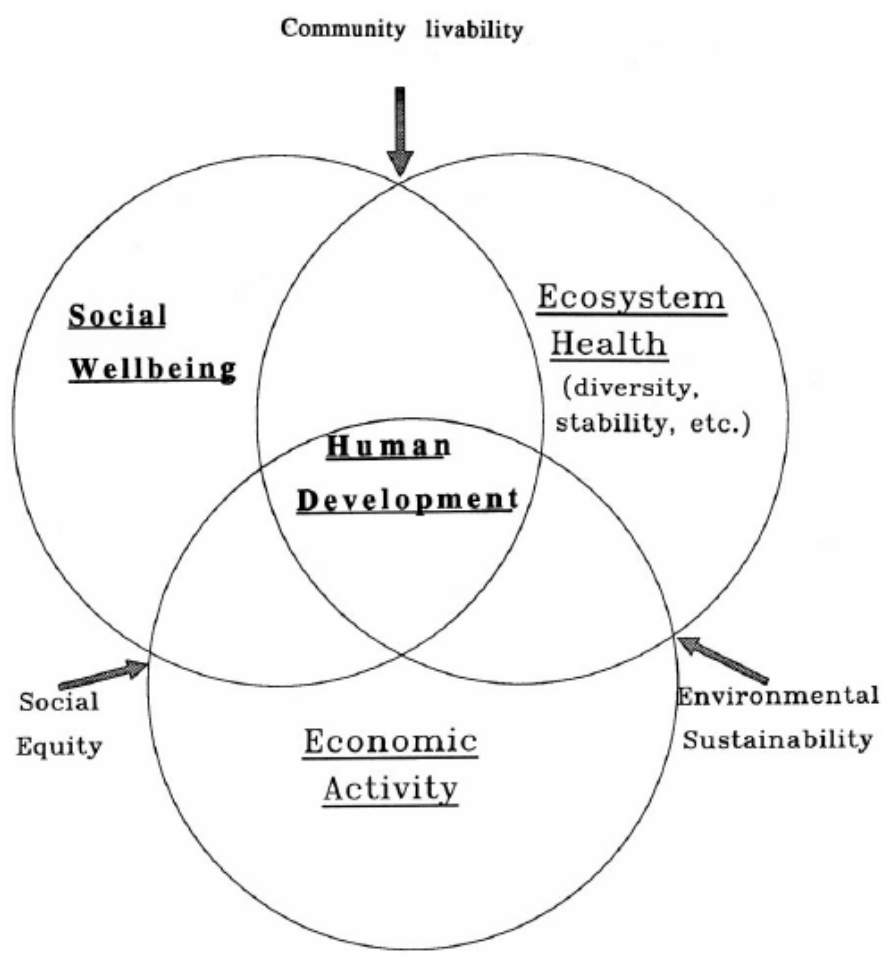

Figure 1 - Human Model Development (from Hancock, 1999).

Human must be considered in its different dimensions living and working in a city context. Sustainability as seen by Zink (2008), must incorporate a broader concept showing the integration of city' goals for sustainable development including Integrated Management which must consider the Key Performance Indicators for corporate sustainability. This integration can contribute to the local Sustainable Goals for Development where is assumed that citizens have good quality of life.

\section{Conclusion}

It was our goal to explore a new line of discussion about the inclusion of an occupational layer on the global cities concept. The results from the systematic literature review shows evidence that this layer is missing.

Authors strong believe that this layer is missing, as citizens that are leaving on cities can also work on those cities. Cities must also be seen as working systems, with the same needs and requirements in terms of safety and well-being that are considered for other systems. The ensemble analysis of the three search words used on this research showed that sustainability, occupational and global cities are often analyzed with a non-integrated approach. Further studies are required helping the characterization of the occupational layer. This can contribute to the definition of system works requirements that can contribute to the cities' goals for sustainable development. 


\section{References}

Rode, P. and Burdett, R. (2011). Cities: investing in energy and resource efficiency. Published in United Nations Environment Program, (corp. ed.) Towards a green economy: pathways to sustainable development and poverty eradication. United Nations Environment Program, pp. 453-492.

Zink, K. (2014). Designing sustainable work systems: The need for a systems approach. Applied Ergonomics, 44 (1), pp. 126-132.

Dyllick, T. and Hockerts, K. (2002). Beyond the business case for corporate sustainability. Business Strategy and the Environment, 11 pp. 130-141.

Insch,A. and Florek, M. (2008) "A great place to live, work and play: Conceptualising place satisfaction in the case of a city's residents". Journal of Place Management and Development, 1 (2), pp.138-149.

Węziak-Białowolska, D. (2016) Quality of life in cities-Empirical evidence in comparative European perspective. Cities, 58 pp. 87-96.

Timberlake, M., Wei, Y., Ma, X., Hao, J.(2014). Global cities with Chinese characteristics Cities, Part B, 41 pp. 162-170.

Csomós,G. and Tóth, G. (2016). Exploring the position of cities in global corporate research and development: A bibliometric analysis by two different geographical approaches. Journal of Informetrics, 10 (2), pp. 516-532.

Sassen, S. (2005) The Global city: Introducing a concept. Brown Journal of World Affairs. XI (2), pp. 27-43.

Buffel, T., Phillipson, C. (2016) Can global cities be age-friendly cities? Urban development and ageing populations. Cities, 55, pp. 94-100.

Sasaki, M. (2010). City, Culture and Society (CCS) - Opening up new horizon of urban studies. City, Culture and Society, 1 (1), pp. 1-2.

Nieuwenhuijsen, M.J., Khreis, H. (2016). Car free cities: Pathway to healthy urban living. Environment International, 94, pp. 251-262.

Lazaroiu,G., Roscia, M.C. (2012). Definition methodology for the smart cities model. Energy, 47 (1), pp. 326-332.

Rasmussen J. 2000. Human factors in a dynamic information society: where are we heading? Ergonomics. 43(7): 869-879.

Loureiro, I., Leão, C.P. and Arezes. P.M. (2010). Management of the Benefits on the Client's Involvement on Ergonomic Analysis. In Tenreiro de Magalhães, Sérgio, Jahankhani, Hamid, Hessami, Ali G. (Eds.), Global Security, Safety, and Sustainability Communications in Computer and Information Science, 92, 1-8. Braga: Springer Berlin Heidelberg. (Web of Science Accession Number: WOS:000288878900001.

Castellucci, H.I., Arezes, P.M., Molenbroek, J.F.M,R., Bruin and Viviani, C. (2016): The influence of school furniture on students' performance and physical responses: results of a systematic review. Ergonomics, DOI: 10.1080/00140139.2016.1170889

Floater, G. and Rode, P. Cities and the New Climate Economy: the transformative role of global urban growth. Cities and the New Climate Economy: the transformative role of global urban growth. NCE Cities-Paper 01.

ViennaOriginal Research Article

Hatz, G. (2008). Vienna. Cities, 25 (5), pp. 310-322.

Madaleno,I., Gurovich, A. (2004). "Urban versus rural" no longer matches reality: an early public agroresidential development in periurban Santiago, Chile. Cities, 21 (6) pp. 513-526.

Özcüre,G., Demirkaya, H., Eryiğit, N. (2011). The sustainable company and employee participation as a part of the solution to triple crisis in the European Union And Turkey: Example of OMV Samsun Elektrik. Procedia - Social and Behavioral Sciences, 24, pp. 1274-1287.

Schwengel, H. (2008). Emerging powers as fact and metaphor: Some European ideas. Futures, 40 (8), pp. 767-776.

Hancock, T. (1999). Health care reform and reform for health: creating a health system for communities in the 21 st century. Futures, 31 (5), pp. 417-436. 